\title{
Optimization method and application research of dewatering design for complicated foundation pits
}

\author{
Zhengyong Liu ${ }^{1}$, Biao $\mathrm{Li}^{1}$ \\ ${ }^{1}$ Zhejiang Shunjiang Construction Group CO.LTD, Shaoxing, Zhejiang Province, 312300, China \\ Keywords: deep foundation pits; dewatering design; Three-dimensional numerical simulation; optimization designating.
}

\begin{abstract}
The groundwater control system of complex deep foundation pit engineering is designed based on experience and analysis of items such as dewatering, anti-inrushing, water-recharging, etc. Three-dimensional numerical simulation methods are used to optimize the design. By repeatedly adjusting the design items and simulating the working system, a safer, more reasonable and economical design scheme can be confirmed by comparing the analysed results.
\end{abstract}

\section{Introduction}

Super high-rise building projects often entail the large-scale deep and complicated foundation pit. Dewatering is widely used to reduce the piezometric levels around foundation pits while these pits excavating; if improperly handled, however, it can easily cause land subsidence, geological disasters, and major security incidents.

Design and optimization of dewatering to these complicated foundation pits are difficult and complicated. The three-dimensional numerical simulation method is believed to be the basic theory of optimization design of engineering structures of dewatering in deep foundation pit.

\section{The site Project introduced}

\subsection{Engineering background}

The site is located near Jinji Lake in Suzhou City of Jiangsu Province, China. The area of the site is 25,000 $\mathrm{m} 2$. The buildings on the site are a super high-rise tower which is planned to be $700+\mathrm{m}$ high, a 8 -storey commercial annex, and a large area 5 -storey basement (Area I) and a two-floor basement (Area II). The site and its surroundings are presented in Fig. 1.

\subsection{Geological conditions}

The foundation mainly consists of saturated clayey soil, silty soil, and sandy soil, with layers (8), (10), and (12) divided into several sub layers. The strata distributions are listed in Table 1.

\subsection{Hydrogeological condition}

As show in the Fig.2, the groundwater basin of the site is composed of several aquifers separated from each other by multi-aquitards. The confined water in (9) and (11) should be taken into considered while the pit is excavated. 


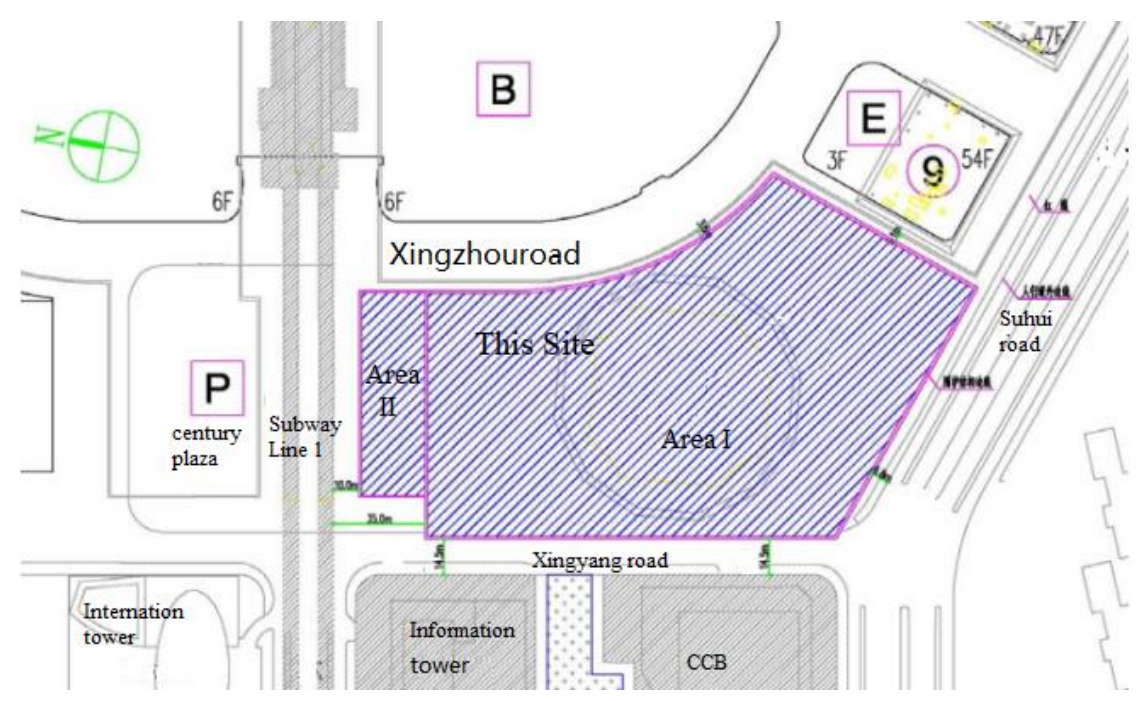

Fig.1. Site information and environment.

Table 1. The distribution of soil layers.

\begin{tabular}{|c|c|c|c|c|c|}
\hline $\begin{array}{l}\text { Strata } \\
\text { serial }\end{array}$ & Name of soil layer & $\begin{array}{l}\text { Layer thickness } \\
\qquad(\mathrm{m})\end{array}$ & $\begin{array}{c}\text { Elevation of layer } \\
\text { top }(\mathrm{m})\end{array}$ & $\begin{array}{c}\text { Elevation of layer } \\
\text { bottom (m) }\end{array}$ & $\begin{array}{c}\text { Permeability coefficient } \\
\text { by indoor test }(\mathrm{cm} / \mathrm{s})\end{array}$ \\
\hline (1) 1 & impurity fill & $0.7 \sim 8.2$ & $0.6 \sim-0.7$ & $2.15 \sim-5.10$ & \\
\hline (4) & silty clay & $1.1 \sim 6.1$ & $2.15 \sim-4.22$ & $-2.09 \sim-5.52$ & $1.0 \mathrm{E}-6$ \\
\hline (5) & sandy silt & $2.6 \sim 12.4$ & $-2.09 \sim-5.52$ & $-6.49 \sim-16.86$ & $8 \mathrm{E}-04$ \\
\hline (6) & silty clay & $4.1 \sim 22.4$ & $-6.49 \sim-16.86$ & $-17.60 \sim-31.20$ & $5 \mathrm{E}-05$ \\
\hline (8) 1 & silty clay & $1.1 \sim 5.3$ & $-17.6 \sim-21.04$ & $-20.96 \sim-24.42$ & $1 \mathrm{E}-06$ \\
\hline$(8) 2$ & Sandy clay and silt & $1.2 \sim 11.6$ & $-20.96 \sim-30.03$ & $-28.82 \sim-33.69$ & $3 \mathrm{E}-05$ \\
\hline (9) & silt & $5.2 \sim 16.4$ & $-28.75 \sim-33.69$ & $-35.96 \sim-46.45$ & $2 \mathrm{E}-03$ \\
\hline (10) 1 & silty clay & $4.2 \sim 23.6$ & $-35.96 \sim-46.45$ & $-49.72 \sim-61.87$ & $3 \mathrm{E}-06$ \\
\hline (10) $\mathrm{t}$ & Silty sand & $1.5 \sim 5.7$ & $-49.72 \sim-57.83$ & $-53.83 \sim-60.44$ & $1 \mathrm{E}-03$ \\
\hline (10) 2 & silty clay & $1.2 \sim 14.0$ & $-51.05 \sim-60.44$ & $-56.69 \sim-71.38$ & $5 \mathrm{E}-06$ \\
\hline (11) & Silt and silty clay & $1.1 \sim 15.6$ & $-55.42 \sim-68.05$ & $-66.88 \sim-72.36$ & $3 \mathrm{E}-04$ \\
\hline (12) 1 & clay & $6.7 \sim 13.0$ & $-66.88 \sim-72.36$ & $-78.03 \sim-81.83$ & $3 \mathrm{E}-06$ \\
\hline (12) 2 & silty clay & $4.4 \sim 10.7$ & $-78.03 \sim-81.83$ & $-85.26 \sim-89.57$ & \\
\hline (13) & Silty sand & $0.9 \sim 10.8$ & $-85.26 \sim-89.57$ & $-97.53 \sim-101.44$ & \\
\hline
\end{tabular}




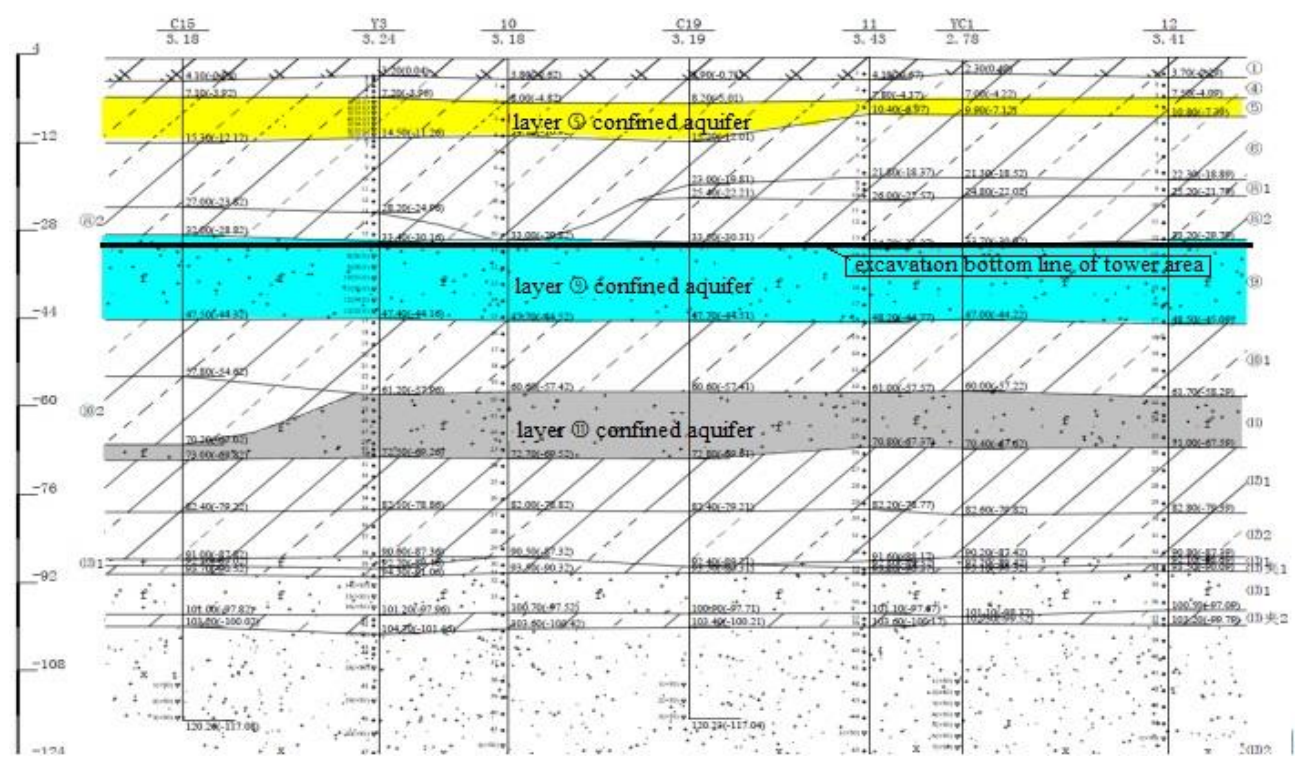

Fig.2 Site typical soil profile and properties

\section{Introduction of pit engineering}

\subsection{Foundation pit partitions}

Fig. 3 and Fig.4 present the foundation pit partitions. Area $\mathrm{I}$ is the foundation area whose basement are five floors. The basement of Area II is two floors.

The whole area of the foundation pit is about 26260 $\mathrm{m} 2$, the foundation pit of Area I is $23430 \mathrm{~m} 2$, and the area of Area II is $2830 \mathrm{~m} 2$. The circumference of the foundation pit are $695 \mathrm{~m}$ (length).

\subsection{Pit enclosure design}

Fig.3 shows the layout plan of the foundation pit enclosure design. The diaphragm wall of Area II can cut off the groundwater flow of layer (5).The diaphragm wall of Area $\mathrm{I}$ is about $63 \mathrm{~m}$ deep, which can cut off the groundwater flow of layer (9). The high-pressure jet grouting piles inside the diaphragm wall are designed to block the groundwater leaking from outside through the gap of the wall.

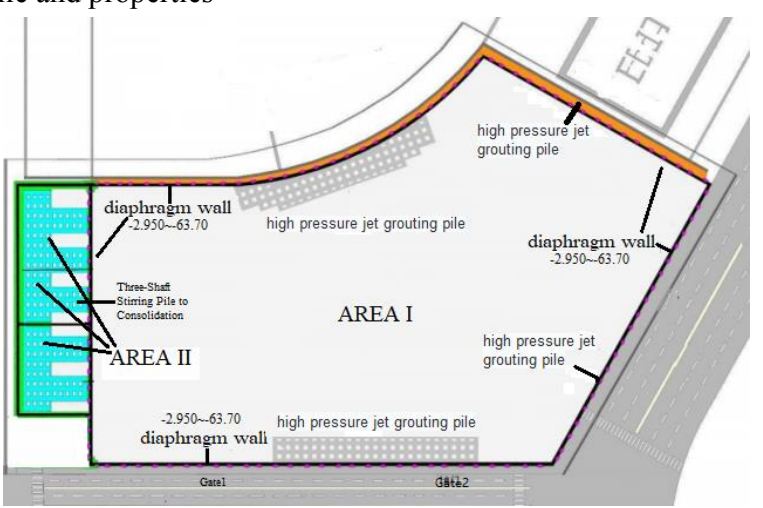

Fig. 3. Foundation pit enclosure design layout plan.

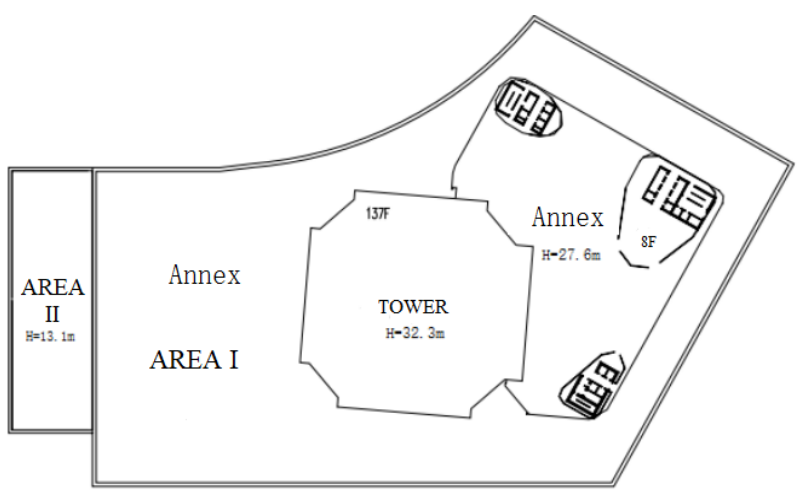

Fig.4. Avenger Excavation depth of partitions (max depth: Tower 36m, Annex 32m, Area II 14m).

\subsection{Construction methods of foundation pits}

According to the construction arrangement, Area I will be dug first and then its underground-structure will be built, with the construction of Area II postponed. 
The excavation depth of the foundation pits is presented in Fig. 4.

\section{Initial design scheme of groundwater control system}

\subsection{Dewatering design schemes}

\subsubsection{The dewatering design of Area II}

The pit depth of Area II is about $13.1 \mathrm{~m}$ (Fig. 3). The groundwater level while digging should be controlled 1 $\mathrm{m}$ below the working plane, so the numbers of the dewatering wells are 11 , which is one well per $250 \mathrm{~m} 2$ according to the experiments and the calculated results.

\subsubsection{The dewatering design of Area I}

There are five floors in the basement of Area I, and their pit depth is about $27 \mathrm{~m} \sim 36 \mathrm{~m}$. because of the diaphragm wall cutting off the water movement of layers (5) and (9) mainly, supplement to the groundwater of layers (5) and (9)is limited.

According to the experiments, the numbers of the dewatering wells are 93, and the depth of the wells are designed to be different for the tower area and the podiums area.

The dewatering initial design schemes for both Area I and Area II is presented in Fig. 5.

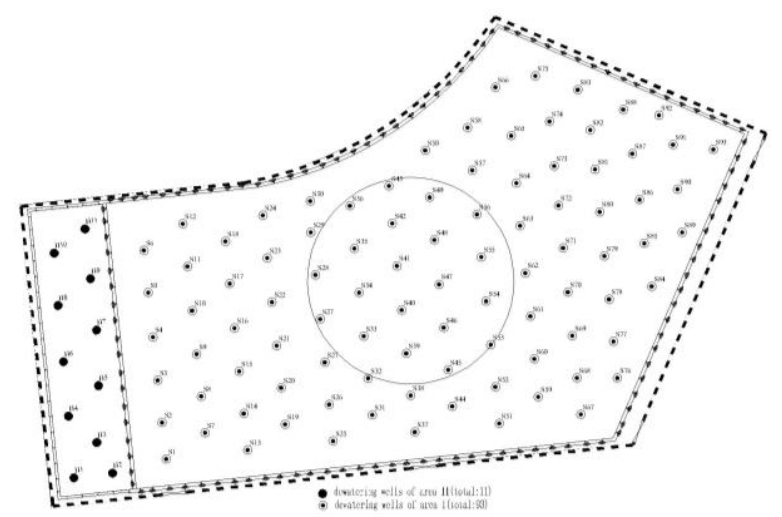

Fig.5. The design schemes of dewatering wells.

\subsection{Design for anti-inrush}

The groundwater in layer (11) has high pressure and the diaphragm wall is not deep enough to block the water movement. Formula 1 can be used to judge if the water-inrush will happen.

$$
\frac{\gamma_{\mathrm{m}}(t+\Delta t)}{p_{w}} \geq 1.1
$$

Where:

$\gamma_{\mathrm{m}}$ is the saturated unit weight of the soil above permeable stratum $\left(\mathrm{kN} / \mathrm{m}^{3}\right)$.

$t+\Delta t$ is the depth between the top of permeable stratum to the bottom of the foundation $\operatorname{pit}(\mathrm{m})$.

$P_{w}$ is the aquifer pressure $(\mathrm{kPa})$.

Table 2 shows the results whether the in-rush will be possibly happened while being in the process of foundation pit construction.

Table 2. The judgment of in-rush to confined groundwater in layer(11).

\begin{tabular}{|c|c|c|c|c|c|}
\hline $\begin{array}{c}\text { pit } \\
\text { Partition }\end{array}$ & $\begin{array}{c}\text { Excavation } \\
\text { depth(m) }\end{array}$ & $\begin{array}{c}\text { Elevation } \\
\text { of } \\
\text { confined } \\
\text { aquifer } \\
\text { top(m) }\end{array}$ & $\begin{array}{c}\text { Groundwater } \\
\text { lever table } \\
(\mathrm{m})\end{array}$ & $\frac{\gamma_{\mathrm{m}}(t+\Delta t)}{p_{w}}$ & $\begin{array}{c}\text { True or } \\
\text { false }\end{array}$ \\
\cline { 1 - 1 } $\begin{array}{c}\text { Area } \\
\text { I-Tower }\end{array}$ & 36 & \multirow{2}{*}{55.6} & 11.1 & 0.88 & true \\
\cline { 1 - 1 } $\begin{array}{c}\text { Area } \\
\text { I-Annex }\end{array}$ & 32 & & 1.04 & true \\
\cline { 1 - 2 } Area II & 30 & & 1.11 & false \\
\hline
\end{tabular}

The de-pressuring initial design schemes for Area $\mathrm{I}$ is presented in Fig.6.

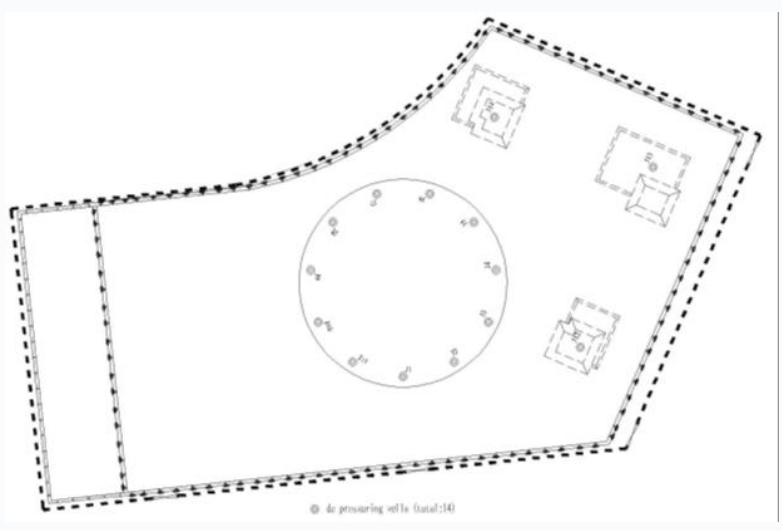

Fig.6. The design schemes of De-pressuring wells.

\section{Optimal Design of Dewatering}

\subsection{Introduction of the optimization method}

On the basis of the initial design scheme, an optimization procedure should be taken. 
Numerical simulation methods are used to analyze how the groundwater control system working, and to judge whether the scheme meet the construction requirements. These adjustment measures usually include the wells' numbers, location, length, diameter, and structure, etc.

By repeatedly adjusting, simulating, and comparing the results, and a safer, more reasonable, and more economical design scheme can be confirmed.

\subsection{Numerical simulation of foundation pit dewatering}

The commercial software Visual Modflow which is a kind of finite difference method (FDM), is adopted as a numerical tool for this case.

The 3D mathematical model of confined aquifer unsteady flow is as follows:

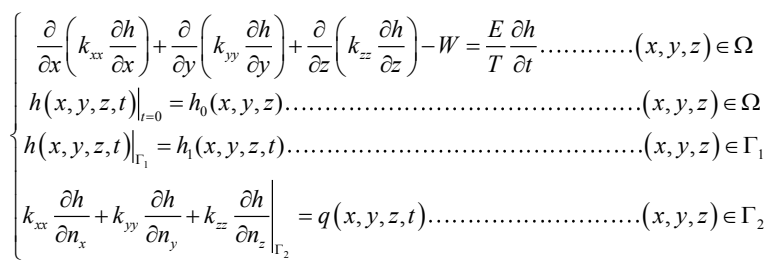

where

$$
\begin{aligned}
& E=\left\{\begin{array}{cc}
S & \text { confined aquifer } \\
S_{y} & \text { unconfined aquifer }
\end{array}\right. \\
& T= \begin{cases}M & \text { confined aquifer } \\
B & \text { unconfined aquifer }\end{cases} \\
& S_{s}=\frac{S}{M} ;
\end{aligned}
$$

where

$S$ is the storage coefficient; $S_{\mathrm{y}}$ is the specific yield; and $M$ is the thickness of confined aquifer $(m)$.

$B$ is the thickness of unconfined aquifer (m).

$k_{\mathrm{xx}}, k_{\mathrm{yy}}$ and $k_{\mathrm{zz}}$ are the $\mathrm{x}, \mathrm{y}, \mathrm{z}$ main direction osmotic coefficients $(m / d)$.

$h$ is the hydraulic head value of point $(\mathrm{x}, \mathrm{y}, \mathrm{x})$ at time $\mathrm{t}(m)$.

$W$ is a source and sink term $(1 / d) ; h_{0}$ is initial hydraulic head of computational domains $(m)$;

$h_{1}$ 为 is hydraulic head value of the first boundary (m); $S_{\mathrm{s}}$ is the storage coefficient $(1 / m)$.

$t$ is time $t(d)$.

$\Omega$ is computational domain; $\Gamma_{1}$ is the first boundary, $\Gamma_{2}$ is the second boundary.

$n_{\mathrm{x}} 、 n_{\mathrm{y}}, n_{\mathrm{z}}$ is unit vector of the outward normal of the boundary in the $\mathrm{x}, \mathrm{y}, \mathrm{z}$ direction.

$q$ is the lateral supply per unit area of $\Gamma_{2}\left(\mathrm{~m}^{3} / d\right)$.

The results show that the optimization depressurizing scheme can meet the requirement of pit excavation construction.

\section{Economic comparison}

The comparison between optimization scheme and initial scheme are presented as table 3 :

Table 3. The comparison between optimization scheme and initial scheme.

\begin{tabular}{|c|c|c|c|c|c|}
\hline \multirow{2}{*}{ Area } & purpose & \multicolumn{2}{|c|}{$\begin{array}{c}\text { Optimizati } \\
\text { on scheme }\end{array}$} & \multicolumn{2}{c|}{$\begin{array}{c}\text { Initial } \\
\text { scheme }\end{array}$} \\
\cline { 2 - 6 } & & $\mathrm{N}$ & $\mathrm{D}(\mathrm{m})$ & $\mathrm{N}$ & $\mathrm{D}(\mathrm{m})$ \\
\hline \multirow{2}{*}{ Area II } & dewatering & 5 & 19 & 11 & 19 \\
\hline \multirow{2}{*}{ Area I } & dewatering & 102 & $31 \sim 48$ & 93 & 48 \\
\cline { 2 - 6 } & anti-inrush(Area-Tower) & 8 & 73 & 14 & 73 \\
\hline \multirow{2}{*}{$\begin{array}{c}\text { Pit } \\
\text { outside }\end{array}$} & recharge(layer(9) & -- & 48 & 13 & 49 \\
\cline { 2 - 6 } & recharge(layer(11) & 7 & 73 & 13 & 73 \\
\hline
\end{tabular}

$\mathrm{N}=$ number, $\mathrm{D}=$ depth

The comparison between the initial design scheme and the optimization design scheme are presented in Table 4. This data shows that the economic effect of the optimization is obvious and the dewatering system costs would decrease by about $35 \%$ after optimization. 
Table 4. The comparison between initial design and the optimization design.

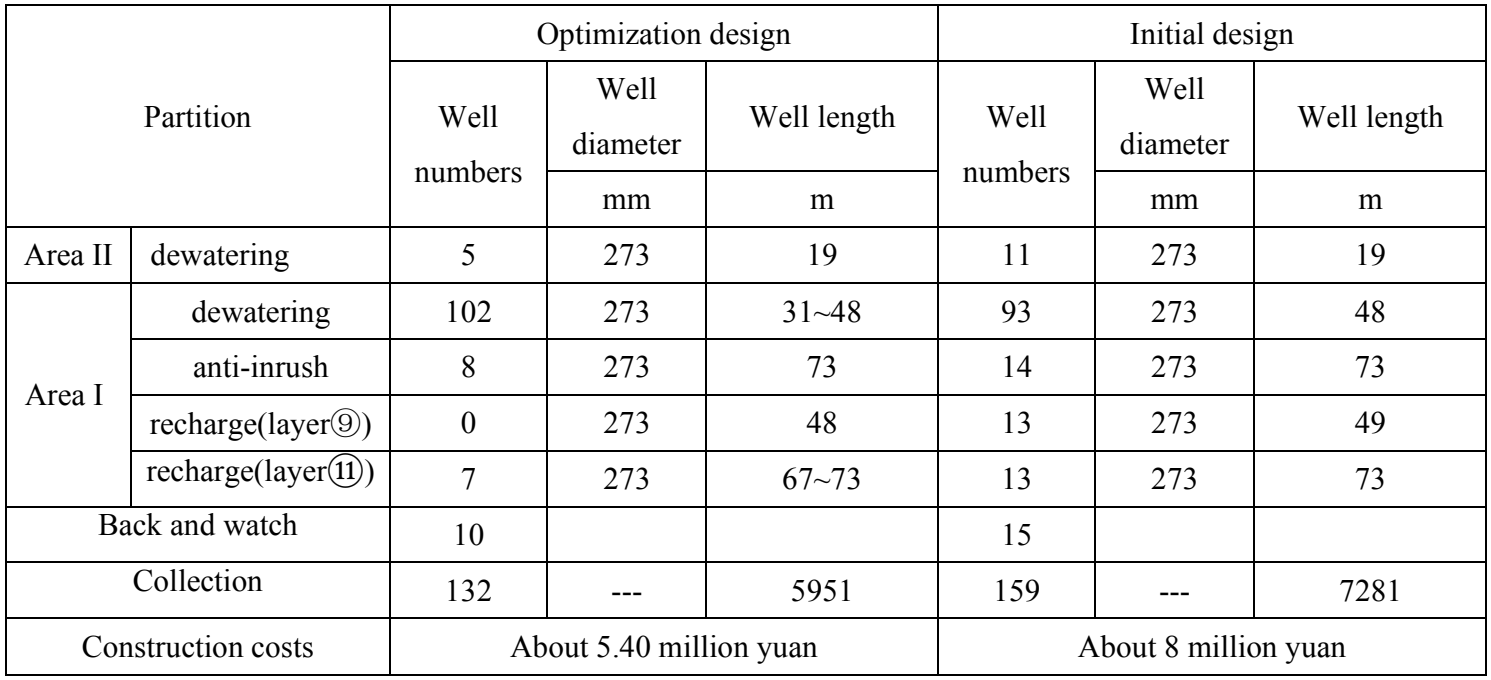

\section{Conclusions}

The dewatering design of complicated pit excavation should take many factors into consideration. Adjusting the arrangement and analyzing the dewatering system with numerical simulation many times allows a relatively superior design to be obtained.

The 3D numerical simulation analysis method is an effective analytical method for fining the most optimal theoretical selection. However, considering the deviation of software calculation and the complexity of engineering practice, it is reasonable to combine the analysis results with engineering experience to determine the final selection.

Project practice shows that this method can meet practical requirements and obtain better economic benefits.

\section{References}

1. X. An, D. Zuo, M. Li, W. Pei,etc. "Study on coupling model for three-dimensional seepage and land subsidence of deep foundation pit dewatering." Proceedings of the 2014 International Conference on Engineering Technology and Applications, (2014).

2. J. Aviles, L.E. Perez Rocha, Regional subsidence of Mexico City and its effects on seismic response. Soil Dynamics and Earthquake Engineering 30, (2010).

3. Y. Hou, D. Yu, X. Ai, J. Ye, X. Huang, Research and Application of Dewatering Key Technology of Ultra-large and Deep Foundation Excavation in Tianjin
Goldin Finance 117 Project, Construction technology 40, (2014).

4. J. Zeng, etc. Geotechnical investigation report of the Suzhou Zhongnan center buildings. Shanghai Geotechnical Investigations and Design Institute Co.Ltd (SGIDI), Shanghai (in Chinese), (2013).

5. Z. LI, J. LI, P. Song, F. Yang. Application of Numerical Modeling to Dewatering Design for Foundation Pit, Ground water, 38, (2016).

6. Q. Liu, C. Che. Design of Deep Excavation Dewatering Under Complex Geological Conditions of Yangtze River Floodplain, Exploration Engineering: Rock \& Soil Drilling and Tunneling, 40, (2013).

7. Z. Luo, Y. Zhang, Y. Wu. Finite Element Numerical Simulation of Three Dimensional Seepage Control for Deep Foundation Pit Dewatering. Journal of Hydrodynamics. 20 ,(2008).

8. Z.Luo, J. Liu, L. Li, C. Qu. Numerical simulation based on the three dimensional full coupling model between deep foundation pit dewatering and land-subsidence(in Chinese), Journal of Hydrodynamics, Ser. A, 21, (2006).

9. N. Zhou, P. A. Vermeer, R. Lou, Y. Tang, S. Jiang. Numerical simulation of deep foundation pit dewatering and optimization of controlling land subsidence, Engineering Geology, 114, (2010). 